\title{
New data on some species of Monogenea and Digenea parasites of marine fish from the coast of the State of Rio de Janeiro, Brazil
}

\author{
Novos dados sobre algumas especies de Monogenea e Digenea parasitas de \\ peixes marinhos da costa do estado do Rio de Janeiro, Brasil \\ Berenice M. M. Fernandes*; Anderson D. N. Arci; Simone C. Cohen
}

Laboratório de Helmintos Parasitos de Peixes, Departamento de Helmintologia, Instituto Oswaldo Cruz, Fundação Oswaldo Cruz

Received February 19, 2008

Accepted February 2, 2009

\begin{abstract}
Fifty four specimens of marine fish belonging to seven species collected from the coast of the State of Rio de Janeiro, Brazil were examined for helminths, and results relating to Monogenea and Digenea are presented. The monogeneans Metamicrocotyla macracantha, Microcotyle pomatomi and Gotocotyla acanthura are reported in new hosts. The digeneans Parahemiurus merus, Lecithochirium microstomum, Gonocercella pacifica, Aponurus laguncula, Gonocerca trematomi and Lampritrema miescheri are reported in new hosts, and the latter two species are also reported for the first time in Brazil.
\end{abstract}

Keywords: Monogenea, Digenea, Brazil, marine fish.

\section{Resumo}

Cinquenta e quatro espécimens de peixes marinhos pertencentes a sete espécies coletados do litoral do estado do Rio de Janeiro, Brasil foram examinados para helmintos, os resultados referentes a Monogenea e Digenea são apresentados. Os monogenéticos Metamicrocotyla macracantha, Microcotyle pomatomi e Gotocotyla acanthura são apresentados em novos hospedeiros. Os digenéticos Parahemiurus merus, Lecithochirium microstomum, Gonocercella pacifica, Aponurus laguncula, Gonocerca trematomi e Lampritrema miescheri são registrados em novos hospedeiros, as duas últimas espécies são também registradas pela primeira vez no Brasil.

Palavras-chave: Monogenea, Digenea, Brasil, peixes marinhos.

\section{Introduction}

A survey on helminths recovered from marine fish was conducted, with the aim of establishing the Monogenea and Digenea fauna of some hosts that are considered to be of commercial importance on the coast of the State of Rio de Janeiro, Brazil. Among the helminths collected, six species of Digenea are reported in new hosts, and two of them are also recorded for the first time in Brazil; and three species of Monogenea are reported in new hosts.

\section{Material and Methods}

From July 2005 to September 2006, 54 specimens of marine fish belonging to seven species were examined. The fish were obtained from the fish market of the municipality of Niterói, State of Rio de Janeiro, and had been caught in the waters surrounding this

\footnotetext{
*Corresponding author: Berenice M. M. Fernandes

Laboratório de Helmintos Parasitos de Peixes, Departamento de Helmintologia, Instituto Oswaldo Cruz, Fundação Oswaldo Cruz, Av. Brasil 4365, CEP 21045-900 Manguinhos, Rio de Janeiro - RJ, Brazil; e-mail: berenice@ioc.fiocruz.br
}

area, located at $22^{\circ} 56^{\prime} 26^{\prime \prime} \mathrm{S}$ and $43^{\circ} 02^{\prime} 41^{\prime \prime} \mathrm{W}$. The fish were identified in accordance with Szpilmam (2000). The Monogenea and Digenea were cold fixed in AFA and 5\% formaldehyde, respectively, under light cover glass pressure. The specimens were stained with Langeron's alcoholic acid carmine, dehydrated by means of an ethyl alcohol series, cleared using beechwood creosote and mounted in Canada balsam as permanent slides. The main measurements and figures are presented only for the species that are reported for the first time in Brazil. The measurements are given in micrometers unless otherwise stated, and the range is presented followed by the mean in parentheses. Figures were drawn with the aid of a drawing tube. The specimens studied have been deposited in the Helminthological Collection of Instituto Oswaldo Cruz (CHIOC), in Brazil. Monogenea were identified in accordance with Yamaguti (1963) and Digenea in accordance with Yamaguti (1971), Gibson et al. (2002) and Jones et al. (2005). The scientific names of the parasitized fish are given in alphabetical order, with the family, common name, number of specimens examined/parasitized, prevalence of infection with 
Monogenea and Digenea, and parasites found in each, followed by the intensity of parasites per infected fish. New host records are represented by $(\mathrm{NH})$.

\section{Results and Remarks}

\section{Host-Parasite list}

Genypterus brasiliensis (Regan, 1903), Ophidiidae (5/3)

Digenea $(P=60 \%)$

Parahemiurus merus (Linton, 1910) Yamaguti, 1938 (8)

CHIOC n. 37.024 a-b

Pseudolepidapedon brasiliensis (Fernandes \& Souza, 1973)

Ramadan, 1987 (5, 3) CHIOC n. 37.028 a-c

Menticirrbus americanus (Linnaeus, 1758), Sciaenidae (1/1)

Digenea $(P=100 \%)$

Prosorhynchus sp. (1) CHIOC n. 37.034

Micropogonias furnieri (Desmarest, 1823), Sciaenidae (8/5)

Monogenea ( $\mathrm{P}=62 \%)$

Pterinotrematoides mexicanum Caballero \& Bravo-Hollis,

1955 (1, 2, 4, 4, 26) CHIOC n. 37.014,37.018

Macrovalvitrema sinaloense Caballero \& Bravo-Hollis,

$1955(1,1,4)$ CHIOC n. 37.019a-b

Digenea $(\mathrm{P}=12 \%)$

Gonocerca trematomi Byrd, 1963 (1) CHIOC n. 37.020

Lecithochirium microstomum Chandler, 1935 (6) CHIOC

n. $37.021 \mathrm{a}-\mathrm{b}$

Mycteroperca sp., Serranidae (9/3)

Digenea $(\mathrm{P}=33 \%)$

Gonocercella pacifica Manter, 1940 (1,27) CHIOC n. 37.015a-c

Lecithochirium microstomum Chandler, 1935 (17) CHIOC n. 37.022

Lampritrema miescheri (Zschokke, 1890) Margolis, 1962

(1) CHIOC n. 37.023

Pagrus pagrus (Linnaeus, 1758), Sparidae (4/3)

Monogenea $(\mathrm{P}=75 \%)$

Anoplodiscus longivaginatus Paraguassú, Luque \& Alves, $2002(1,1)$ CHIOC n. 37.013, 37.016

Echinopelma brasiliensis Fábio, 1999 (1) CHIOC no.

37.017

Pseudopercis numida (Miranda \& Ribeiro, 1903), Pinguipedidae $(22 / 6)$

Monogenea $(\mathrm{P}=27 \%)$

Microcotyle pseudopercis Amato \& Cézar, 1994 (1, 1, 1,

2, 6, 11) CHIOC n.37.029 a-c

Digenea $(\mathrm{P}=4 \%)$

Aponurus laguncula Looss, 1907 (1) CHIOC n. 37.031
Cynoscion leiarchus (Cuvier, 1830), Sciaenidae (7/5)

Monogenea $(\mathrm{P}=57 \%)$

Metamicrocotyla macracantha (Alexander, 1954) $(1,2)$

CHIOC n. 37.026, 37.032 a-b, 37.033

Gotocotyla acanthura (Parona \& Perugia, 1891) $(2,2,2)$

CHIOC n. 37.033

Microcotyle pomatomi Goto, 1899 (6) CHIOC

n. 37.025

Digenea $(\mathrm{P}=43 \%)$

Pleorchis americanus Lühe, 1906 (1,1,4) CHIOC n.37.027,

37.030

Digenea

Family Hemiuridae Looss, 1899

Parahemiurus merus (Linton, 1910) Yamaguti, 1938

Host: Genypterus brasiliensis (NH)

Site of infection: Intestine.

Remarks: P. merus is a cosmopolitan species that has been reported in different host families. In South America, it has been reported from several countries: from Argentina in Engraulis anchoita (TIMI et al., 1999; TIMI, 2003); from Brazil in Anchoa tricolor (TAVARES et al., 2005), Caranx hippos (AMATO, 1983; LUQUE et al., 2000), Caranx latus (LUQUE et al. 2000; LUQUE; ALVES, 2001), Cynoscion leiarchus (AMATO, 1983), Dactylopterus volitans (CORDEIRO; LUQUE, 2005), Haemulon sciurus (KOHN et al. 1982), Harengula clupeola (WALLET; KOHN, 1987), Harengula sp. (TRAVASSOS et al., 1967; AMATO, 1983), Isopisthus parvipinnis (AMATO, 1983), Lycengraulis grossidens (TRAVASSOS et al., 1967), Oligoplites palometa, Oligoplites saliens (TAKEMOTO et al., 1995, 1996), Opisthonema oglinum (FÁBIO, 1988), Pagrus pagrus (PARAGUASSÚ et al., 2002), Parona signata (AMATO, 1983c), Pomatomus saltatrix (GOMES et al., 1972; AMATO, 1983; REGO et al. 1983; LUQUE; CHAVES, 1999), Sardinella aurita (VAZ; PEREIRA, 1930), Sardinella sp. (FEIJÓ et al., 1979; RODRIGUES et al., 1990), Selene setapinnis (CORDEIRO; LUQUE, 2004), Tylosurus acus (TAVARES et al., 2004) and Urophycis brasiliensis (ALVES et al., 2004); from Colombia in Oligoplites saurus (ROMERO; GALEANO, 1981); from Ecuador in Anchovia arenicola and Opisthonema libertate (MANTER, 1940); from Galapagos in Eugralis ringens (BRAY, 1990); from Uruguay in Eugralis anchoita (TIMI et al., 1999); and from Venezuela in Calamus bajonado (FISCHTHAL; NASIR, 1974) and Orthopristis ruber (CENTENO et al., 2002).

\section{Lecithochirium microstomum Chandler, 1935}

Host: Mycteroperca sp. (NH)

Site of infection: Intestine.

Remarks: This species has been already reported from Argentina in Engraulis anchoita (TIMI et al., 1999, TIMI, 2003), Micropogonias furnieri (SARDELLA et al., 1995) and Parona signata (SZIDAT, 1969; TIMI et al., 1999). From Brazil, it has been reported in several hosts: Caranx hippos, Caranx latus (LUQUE et al., 2000; LUQUE; ALVES, 2001), Cephalopholis fulva (FÁBIO, 2001), Eucinostomus argenteus (WALLET; KOHN, 1987), Menticirrhus americanus (CHAVES; LUQUE, 1998), Micropogonias furnieri (FÁBIO, 1988; ALVES; 
LUQUE, 2000, 2001a, b), Oligoplites palometa, Oligoplites saliens (TAKEMOTO et al., 1995, 1996), Paralonchurus brasiliensis (RIBEIRO et al., 2002, LUQUE et al., 2003), Parona signata (AMATO, 1983), Scombroides occidentalis (VICENTE; SANTOS, 1973), Selene setapinnis (CORDEIRO; LUQUE, 2004), Trichiurus lepturus (FREITAS; KOHN, 1965, WALLET; KOHN, 1987, SILVA et al., 2000a, SILVA et al., 2000b) and Tryrsitops lepidopoides (VICENTE; SANTOS, 1973). From Galapagos, it has been reported in Calamus brachysomus, Caulolatilus sp., Euthynnus alletteratus, Paralabrax humeralis and Paranthias furcifer (MANTER, 1940). From Uruguay, it has been reported in Engraulis anchoita (TIMI et al., 1999). It has also been reported outside South America: from the United States in Lolliguncula brevis, by Overstreet and Hochberg (1975); from Ghana in Trichirus lepturus and Euthynnus alletteratus, by Fischthal and Thomas (1972); from Costa Rica in Fistularia commersoni, by Ponce de Leon et al. (1998); and from Mexico in Euthynnus lineatus, by Castillo-Sanchez et al. (1997).

Family Bucephalidae Poche, 1907

Prosorhynchus sp.

Host: Menticirrhus americanus

Site of infection: Intestine.

Remarks: We collected only an immature specimen. From Brazil, in this genus, the species Prosorhynchus ozakii Manter, 1934, had been already reported in Menticirrhus americanus by Chaves and Luque (1998).

Family Derogenidae Nicoll, 1910

Gonocerca trematomi Byrd, 1963 (Figure 1a)

Host: Micropogonias furnieri $(\mathrm{NH})$

Site of infection: Intestine.

Measurements based on one wholemount: body $5.00 \times 1.54 \mathrm{~mm}$; oral sucker $550 \times 625$; ventral sucker $1,175 \times 1,225$; sucker width ratio 1:2; pharynx $240 \times 250$; seminal vesicle $710 \times 240$; anterior testis $525 \times 700$; posterior testis $625 \times 500$; ovary $275 \times 475$; eggs 37 to $40 \times 17$ to 25 .

Remarks: In South America, this species has been reported in Stromateus stellatus (= Stromateus maculatus) from Argentina by Gaevskaya and Kovaleva (1978). The finding in Micropogonias furnieri on the coast of the State of Rio de Janeiro represents the first report of this species from Brazil.

Gonocercella pacifica Manter, 1940

Host: Mycteroperca sp. (NH)

Site of infection: Intestine.

Remarks: This species was originally described in Trachinotus rhodopus by Manter (1940), from Colombia. It has been recorded from Brazil in Menticirrhus americanus by Chaves and Luque (1998), in Trachinotus ovatus (= Trachinotus glaucus) by Gomes et al. (1978) and in Trachinotus paitensis from Chile and Peru by Luque and Oliva (1993). We recovered young specimens from Mycteroperca sp.

Family Hirudinellidae Dollfus, 1932

Lampritrema miescheri (Zschokke, 1890) Margolis, 1962

(Figure. 1b)

Host: Mycteroperca sp. (NH)

Site of infection: Intestine.
Measurements based on one wholemount: body $21.41 \times 2.00 \mathrm{~mm}$; oral sucker $740 \times 690$; ventral sucker $1,425 \times 1,150$; sucker ratio 1:1.7; pharynx $570 \times 490$; cirrus sac $2,400 \times 475$; anterior testis $460 \times 340$; posterior testis $460 \times 350$ wide; ovary $270 \times 310$ wide, eggs 35 to $45 \times 20$ to 22 .

Remarks: This species was originally described from the northeast Atlantic in Salmo salar and has been reported in its type host and locality by several authors (see GIBSON; BRAY, 1977). From Argentina, it has been reported in Argentina silus as Lampritrema nipponicum Yamaguti, 1940 by Scott (1969) and in Thyrsites atun as Hirudinelloides elongatus by Gaevskaya and Kovaleva (1977); and from the southwest Atlantic in Trachipterus altivelis from Chile by Oliva (1984). On this occasion, L. miescheri is reported for the first time from Brazil.

Family Lecithasteridae Odhner, 1905

Aponurus laguncula Looss, 1907

Host: Pseudopercis numida (NH)

Site of infection: Intestine.

Remarks: In South America, this species has been reported from Argentina in Paralichthys patagonicus (SZIDAT, 1961) and from Brazil in Chaetodipterus faber (FERNANDES et al., 1985), Dactylopterus volitans (CORDEIRO; LUQUE, 2005), Micropogonias furnieri (PEREIRA et al., 2000), Mullus argentinae (LUQUE et al., 2002), Paralonchurus brasiliensis (PEREIRA et al., 2000; LUQUE et al., 2003), Rhomboplites
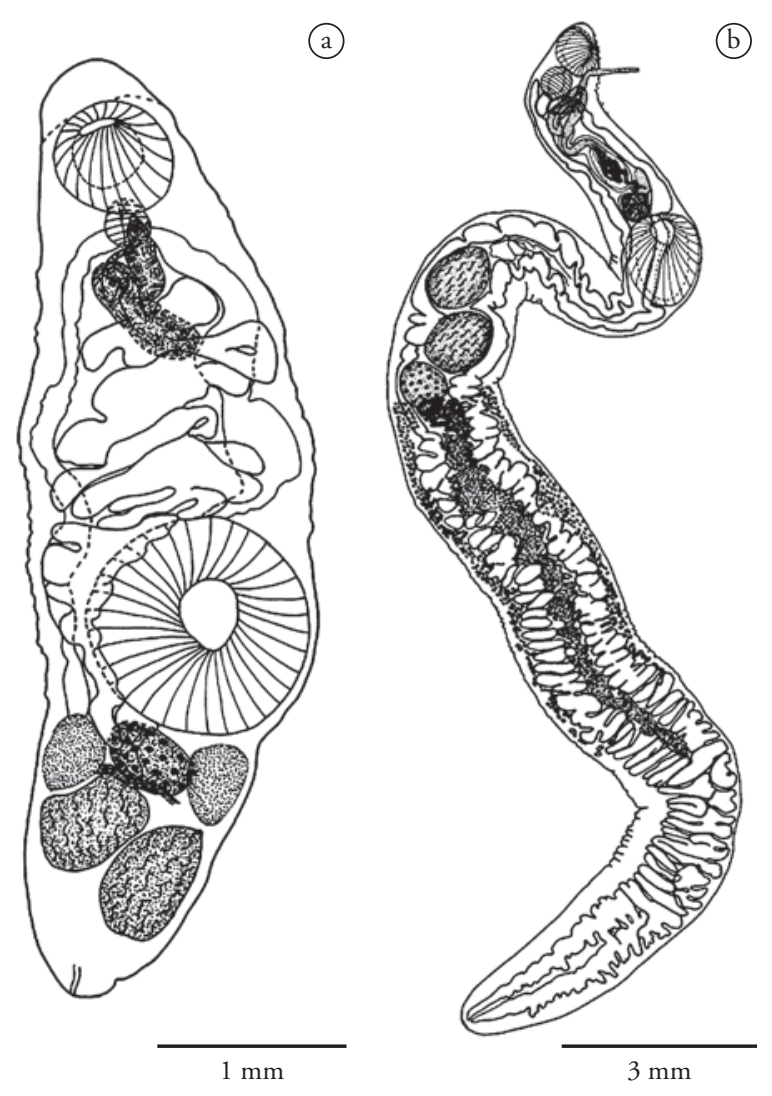

Figure 1. a) Gonocerca trematomi, total, ventral view. b) Lampritrema miescheri, total, dorsal view. 
aurorubens (JUSTO et al., 2003), Scomber japonicus, Trachurus lathami, Umbrina coroides (FERNANDES et al., 1985) and Urophycis brasiliensis (ALVES et al., 2004). It has also been reported in Boops boops from the Spanish coast of the northeast Atlantic by Perez del Olmo et al. (2006); in Siganus oramin from the coast of Kuwait, Arabian Gulf, by Nahhas and Sey (2002); and in Clupea harengus from the eastern English Channel by Bray and MacKenzie (1990).

\section{Monogenea}

Family Microcotylidae Taschenberg, 1879

Metamicrocotyla macracantha (Alexander, 1954) Koratha, 1955

Host: Cynoscion leiarchus $(\mathrm{NH})$

Site of infection: gills.

Remarks: The measurements on the present material are in agreement with previous data, while differing from other Brazilian material in the size of body and clamps. A specimen measuring $2.6 \mathrm{~cm}$ was found, possible due to compression during fixation of the worm. Tantaleán (1974) and Oliva and Muñoz (1985) found specimens measuring up to 22.5 and $23 \mathrm{~mm}$, respectively. This species has been reported in Mugil cephalus and M. curema from several localities: Mexico and Porto Rico (see KOHN et al., 2006); Chile, Peru and Venezuela (see KOHN; COHEN, 1998); USA and Australia (BAKER et al., 2005a, BAKER et al., 2005b); and in Mugil liza and M. platanus from Brazil by Kohn et al. (1994) and Knoff et al. (1997).

\section{Microcotyle pomatomi Goto, 1899}

Host: Cynoscion leiarchus $(\mathrm{NH})$

Site of infection: gills.

Remarks: Microcotyle pomatomi was originally described in Pomatomus saltator from Brazil and has been reported from this host in the type locality (KOHN; COHEN, 1998).

Gotocotyla acanthura (Parona \& Perugia, 1891)

Host: Cynoscion leiarchus $(\mathrm{NH})$

Site of infection: gills.

Remarks: Kohn et al. (1971) described Gotocotyla travassosi in Pomatomus saltator, from Brazil. Subsequently, Lebedev (1984) placed this species in the genus Swakopella. Hayward and Rohde (1999) restudied the paratypes of $G$. travassosi and considered it to be a synonym of Gotocotyla acanthura.

The digeneans Pseudolepidapedon brasiliensis and Pleorchis americanus and the monogeneans Pterinotrematoides mexicanum, Macrovalvitrema sinaloense, Anoplodiscus longivaginatus and Microcotyle pseudopercis had already been reported from Brazil in the hosts reported here (KOHN et al., 2007; KOHN; COHEN, 1998).

\section{References}

ALVES, D. R.; LUQUE, J. L. Metazoários parasitos da corvina, Micropogonias furnieri (Osteichthyes: Sciaenidae) do litoral do Rio de Janeiro. Parasitologia al Día, v. 24, n. 1-2, p. 19-25, 2000.

ALVES, D. R.; LUQUE, J. L. Quantitative aspects of metazoan parasite infrapopulations of Micropogonias furnieri (Osteichthyes: Sciaenidae) from the coastal zone of the state of Rio de Janeiro, Brazil. Parasitologia al Día, v. 25, n. 1-2, p. 30-35, 2001a.

ALVES, D. R.; LUQUE, J. L. Community ecology of the metazoan parasites of white croaker, Micropogonias furnieri (Osteichthyes: Sciaenidae) from the coastal zone of the state of Rio de Janeiro, Brazil. Memórias do Instituto Oswaldo Cruz, v. 96, n. 2, p. 145-153, 2001 b.

ALVES, D. R.; PARAGUASSÚ, A. R.; LUQUE, J. L. Metazoans parasites of the Brazilian codling, Urophycis brasiliensis (Kaup, 1858) (Osteichthyes: Phycidae) from the coastal zone of the State of Rio de Janeiro. Revista Brasileira de Parasitologia Veterinária, v. 13, n. 1, p. 49-55, 2004.

AMATO, J. F. R. Digenetic trematodes of percoid fishes of Florianópolis, Southern Brazil - Pleorchiidae, Didymozoidae and Hemiuridae, with the description of three new species. Revista Brasileira de Biologia, v. 43, n. 1, p. 99-124, 1983.

BAKER, T. G.; PANTE, E.; De BURON, I. Co-occurrence of Naobranchia lizae (Copepoda) and Metamicrocotyla macracantha (Monogenea), gill parasites of the striped mullet Mugil cephalus. Parasitology Research, v. 97 , n. 6, p. 515-520, 2005a.

BAKER, T. G. et al. Size variation of adult polyopisthocotylid Metamicrocotyla macracantha (Monogenea) in relation to host size. Comparative Parasitology, v. 72, n. 2, p. 179-182, 2005b.

BRAY, R. A. A review of the genus Parahemiurus Vaz and Pereira, 1930 (Digenea: Hemiuridae). Systematic Parasitology, v. 15, n. 1, p. 1-21, 1990.

BRAY, R. A.; MACKENZIE, K. Aponurus laguncula Looss, 1907 (Digenea: Lecithasteridae): a report from herring, Clupea harengus L., in the eastern English Channel and a review of its biology. Systematic Parasitology, v. 17, n. 2, p. 115-124, 1990.

CASTILLO-SANCHEZ, E.; GARCIA-PRIETO, L.; PONCE-DE-LEON, G. P. Helminth fauna of Euthynnus lineatus (Perciformes: Scombridae) in Jalisco, Mexico. Revista de Biologia Tropical, v. 45, n. 3, p. 1251-1253, 1997.

CENTENO, L. et al. Comparative analysis of the communities of metazoan parasites in two marine fish species from Cariaco Gulf, Venezuela. Bioagro, v. 14, n. 3, p. 135-144, 2002.

CHAVES, N. D.; LUQUE, J. L. Trematódeos digenéticos parasitos de Menticirrhus americanus (Osteichthyes: Sciaenidae) no litoral do Estado do Rio de Janeiro, Brasil. Parasitologia al Día, v. 22, n. 1-2, p. 33-37, 1998.

CORDEIRO, A. S.; LUQUE, J. L. Community ecology of the metazoan parasites of Atlantic moonfish, Selene setapinnis (Osteichthyes: Carangidae) from the coastal zone of the state of Rio de Janeiro, Brazil. Brazilian Journal of Biology, v. 64, n. 3A, p. 399-406, 2004.

CORDEIRO, A. S.; LUQUE, J. L. Metazoan parasites of flying gurnards, Dactylopterus volitans (Linnaeus, 1758) (Osteichthyes: Dactylopteridae) from the coastal zone of the State of Rio de Janeiro, Brazil. Acta Scientiarum: Biological Sciences, v. 27, n. 2, p. 119-123, 2005.

FÁBIO, S. P. Sobre três Hemiuridae parasitos de peixes do litoral do Estado do Rio de Janeiro. Arquivos da Universidade Federal Rural do Rio de Janeiro, v. 11, n. 1-2, p. 45-49, 1988.

FÁBIO, S. P. Trematódeos parasitos de Priacanthus arenatus Cuvier, 1829 (Pisces, Priacanthidae) em Cabo Frio, RJ, Brasil. Boletim do Museu Nacional, v. 456, p. 1-8, 2001.

FEIJÓ, L. M. F.; RODRIGUES, H. O.; ROdRIGUES, S. S. Contribuição ao conhecimento da fauna helmintológica de sardinhas 
(Sardinella sp.) do litoral do Estado do Rio de Janeiro. Atas da Sociedade de Biologia do Rio de Janeiro, v. 20, p. 23-28, 1979.

FERNANDES, B. M. M.; KOHN, A.; PINTO, R. M. Aspidogastrid and digenetic trematodes parasites of marine fishes of the coast of Rio de Janeiro State. Revista Brasileira de Biologia, v. 45, n. 1-2, p. 109-116, 1985.

FISCHTHAL, J. H.; NASIR, P. Some digenetic trematodes from freshwater and marine fishes of Venezuela. Norwegian Journal of Zoology, v. 22, p. 71-80, 1974.

FISCHTHAL, J. H.; THOMAS, J. D. Additional hemiurid and other trematodes of fishes from Ghana. Bulletin de l'Institut Fondamental de l'Afrique Noire, v. 34, n. 1, p. 9-25, 1972.

FREITAS, J. F. T.; KOHN, A. Nova espécie do gênero Glomericirrus Yamaguti, 1937 (Trematoda: Hemiuridae). Memórias do Instituto Oswaldo Cruz, v. 63, p. 229-235, 1965.

GAEVSKAYA, A. V.; KOVALEVA, A. A. New species of trematodes from fishes of the Falklands-Patagonian Region (South-Western Atlantic). Parazitologyia, v. 11, n. 5, p. 417-423, 1977.

GAEVSKAYA, A. V.; KOVALEVA, A. A. Data on the trematodes of fishes from the South-Western Atlantic. Vestnik Zoologii, v. 1978, n. 3, p. 60-66, 1978.

GIBSON, D. I.; BRAY, R. A. The Azygiidae, Hirudinellidae, Ptychogonimidae, Sclerodistomidae and Syncoeliidae (Digenea) of fishes from the north-east Atlantic. Bulletin of the British Museum Natural History, Zoology, v. 32, n. 6, p. 167-245, 1977.

GIBSON, D. I.; JONES, A.; BRAY, R. A. (Eds.). Keys to the Trematoda. Wallingford: CABI Publishing; London: The Natural History Museum, 2002. 521 p.

GOMES, D. C.; FÁBIO, S. P.; ROLAS, F. J. T. Contribuição para o conhecimento dos parasitas de peixes do litoral do Estado da Guanabara - Parte I. Memórias do Instituto Oswaldo Cruz, v. 70, n. 4, p. 541-553, 1972.

GOMES, D. C.; FÁBIO, S. P.; ROLAS, F. J. T. Contribuição para o conhecimento dos parasitas de peixes do litoral do município do Rio de Janeiro. III. Atas da Sociedade de Biologia do Rio de Janeiro, v. 19, p. 39-42, 1978.

HAYWARD, C. J.; ROHDE, K. Revision of the monogenean family Gotocotylidae (Polyopisthocotylea). Invertebrate Taxonomy, v. 13, n. 3, p. 425-460, 1999.

JONES, A.; BRAY, R. A.; GIBSON, D. I. (Eds.). Keys to the Trematoda. Wallingford: CABI Publishing; London: The Natural History Museum, $2005.745 \mathrm{p}$.

JUSTO, M. C. N.; FERNANDES, B. M. M.; KOHN, A. New host records for Digenea parasites of Brazilian marine fishes. Arquivos de Ciências do Mar, v. 36, p. 101-104, 2003.

KNOFF, M.; LUQUE, J. L.; AMATO, J. F. R. Community ecology of the metazoan parasites of grey mullets, Mugil platanus (Osteichthyes: Mugilidae) from the littoral of the state of Rio de Janeiro, Brazil. Revista Brasileira de Biologia, v. 57, n. 3, p. 441-454, 1997.

KOHN, A.; COHEN, S. C. South American Monogenea: list of species, hosts and geographical distribution. International Journal for Parasitology, v. 28, n. 10, p. 1517-1554, 1998.

KOHN, A.; COHEN, S. C.; BAPTISTA-FARIAS, M. F. D. A redescription of the morphology of Metamicrocotyla macracantha
(Alexander, 1954) Koratha, 1955 (Monogenea, Microcotylidae) from Mugil liza in Brazil. Systematic Parasitology, v. 27, n. 2, p. 127-132, 1994.

KOHN, A.; COHEN, S. C.; SALGADO-MALDONADO, G. Checklist of Monogenea parasites of freshwater and marine fishes, amphibians and reptiles from Mexico, Central America and Caribbean. Zootaxa, v. 1289, p. 1-114, 2006.

KOHN, A.; FERNANDES, B. M. M.; COHEN, S. C. South American Trematodes Parasites of Fishes. Rio de Janeiro: Editora Imprinta, 2007. 318 p.

KOHN, A.; GOMES, D. C.; BÜHRNHEIM, U. Gotocotyla travassosi sp. n., gastrocotilideo de brânquias de enchova (Polistomata). Memórias do Instituto Oswaldo Cruz, v. 69, n. 1, p. 49-51, 1971.

KOHN, A.; MACEDO, B.; FERNANDES, B. M. M. About some trematodes parasites of Haemulon sciurus (Shaw, 1803). Memórias do Instituto Oswaldo Cruz, v. 77, n. 2, p. 153-157, 1982.

LEBEDEV, B. I. System of Monogenea of the suborder Gastrocotylinea. Vladivostok: Academy of Sciences of the USSR, 1984. p. 17-24.

LUQUE, J. L.; ALVES, D. R. Ecologia das comunidades de metazoários parasitos, do xaréu Caranx hippos (Linnaeus) e do xerelete, Caranx latus Agassiz (Osteichthyes, Carangidae) do litoral do estado do Rio de Janeiro, Brasil. Revista Brasileira de Zoologia, v. 18, n. 2, p. 399-410, 2001.

LUQUE, J. L.; CHAVES, N. D. Community ecology of metazoan parasites of bluefish Pomatomus saltator (Linnaeus) (Osteichthyes, Pomatomidae) from the coast of Rio de Janeiro State, Brazil. Revista Brasileira de Zoologia, v. 16, n. 3, p. 711-723, 1999.

LUQUE, J. L; ALVES, D. R.; SABAS, C. S. S. Metazoários parasitos do xaréu Caranx hippos (Linnaeus, 1766) do xerelete Caranx latus Agassiz, 1831 (Osteichthyes: Carangidae) do litoral do Estado do Rio de Janeiro. Contribuiçóes Avulsas sobre a História Natural do Brasil, Série Zoologia, v. 25, p. 1-17, 2000.

LUQUE, J. L.; ALVES, D. R.; RIBEIRO, R. S. Community ecology of the metazoan parasites of banded croaker, Paralonchurus brasiliensis (Osteichthyes: Sciaenidae), from the coastal zone of the state of Rio de Janeiro, Brazil. Acta Scientiarum: Biological Sciences, v. 25, n. 2, p. 273-278, 2003.

LUQUE, J. L.; OLIVA, M. E. Trematodes of marine fishes from the Peruvian faunistic province (Peru and Chile), with description of Lecithochirium callaoensis n. sp. and new records. Revista de Biologia Marinha, v. 28, n. 2, p. 271-286, 1993.

LUQUE, J. L.; PORROZZI, F.; ALVES, D. R. Community ecology of the metazoan parasites of Argentine goatfish, Mullus argentinae (Osteichthyes: Mullidae), from the coastal zone of the state of Rio de Janeiro, Brazil. Revista Brasileira de Parasitologia Veterinária, v. 11, n. 1, p. 33-38, 2002.

MANTER, H. W. Digenetic trematodes of fishes from the Galapagos Islands and the neighboring Pacific. Reports of the Allan Hancock Pacific Expeditions, v. 2, n. 14, p. 325-497, 1940.

NAHHAS, F. M.; SEY, O. Digenetic trematodes from marine fishes of the Coast of Kuwait, Arabian Gulf: Superfamily Hemiuroidea. Acta Zoologica Academiae Scientiarium Hungaricae, v. 48, n. 1, p. 1-20, 2002.

OLIVA, M. Nuevos registros de tremátodos digeneos en peces marinos de la zona de Antofagasta. Ciencia y Tecnologia del Mar - CONA, v. 8, p. 9-15, 1984. 
OLIVA, M.; MUÑOZ, M. A. Microcotyloidea (Platyhelminthes: Monogenea) on marine fishes of Antofagasta, Chile. Estudos Oceanologicos, v. 4, p. 1-8, 1985.

OVERSTREET, R. M.; HOCHBERG Jr., F. G. Digenetic trematodes in cephalopods. Journal of the Marine Biological Association of the United Kingdom, v. 55, p. 893-910, 1975.

PARAGUASSÚ, A. R.; LUQUE, J. L.; ALVES, D. R. Community ecology of the metazoan parasites of the red porgy, Pagrus pagrus (L., 1758) (Osteichthyes: Sparidae) from the coastal zone, state of Rio de Janeiro, Brazil. Acta Scientiarum of Biological Sciences, v. 24, n. 2 , p. 461-467, 2002.

PEREIRA Jr., J.; FERNANDES, B. M. M.; ROBALDO, R. B. Digenea (Trematoda) of Micropogonias furnieri (Desmarest) (Perciformes, Sciaenidae) from Rio Grande do Sul, Brazil. Revista Brasileira de Zoologia, v. 17, n. 3, p. 681-686, 2000.

PÉREZ Del OlMO, A.; RAGA, J. A.; KOSTADINOVA, A.; FERNÁNDEZ, M. Parasite communities in Boops boops (L.) (Sparidae) after the Prestige oil-spill: Detectable alterations. Marine Pollution Bulletin, v. 54, n. 3, p. 266-276, 2006.

PONCE De LEON, G. P.; LEON-REGAGNON, V.; MONKS, S. Theletrum lamothei sp. nov. (Digenea), parasite of Echidna nocturna from Cuajiniquil, Guanacaste, and other digenea of marine fishes from Costa Rica. Revista de Biologia Tropical, v. 46, n. 2, p. 345-354, 1998.

REGO, A. A. et al. Parasitas de anchovas, Pomatomus saltatrix (L.) do Rio de Janeiro. Ciencia e Cultura, v. 35, n. 9, p. 1329-1336, 1983.

RIBEIRO, R. S.; LUQUE, J. L.; ALVES, D. R. Quantitative aspects of parasites of "maria-luiza", Paralonchurus brasiliensis (Osteichthyes: Sciaenidae) from the Rio de Janeiro state coast, Brazil. Revista Universidade Rural - Série Ciências da Vida, v. 22, n. 2, p. 151-154, 2002.

RODRIGUES, H. O.; RODRIGUES, S. S.; FARIA, Z. Contribuição ao conhecimento da fauna helmintológica dos vertebrados de Maricá, Estado do Rio de Janeiro, Brasil. Memórias do Instituto Oswaldo Cruz, v. 85 , n. 1, p. 115-116, 1990.

ROMERO, M.; GALEANO, L. M. Contribucion al conocimiento de parasitos de peces de la Cienaga Grande de Santa Marta (Familias Hemiuridae y Allocreadiidae; Trematoda: Digenea). Lozania, n. 34, p. 5-8, 1981.

SARDELLA, N. H.; ETCHEGOIN, J. A.; MARTORELLI, S. R. Las comunidades parasitarias de Micropogonias furnieri (corvina) en Argentina. Boletin del Instituto Oceanografico da Universidad de Oriente, v. 34, n. 182, p. 41-47, 1995.

SCOTT, J. S. Lampritrema nipponicum (Trematoda) from west Atlantic Argentines. Canadian Journal of Zoology, v. 4, n. 1, p. 139-140, 1969.

SILVA, L. G. O.; LUQUE, J. L.; ALVES, D. R. Metazoan parasites of the Atlantic cutlassfish, Trichiurus lepturus (Osteichthyes: Trichiuridae) from coastal zone of the State of Rio de Janeiro, Brazil. Parasitologia al Día, v. 24, n. 3-4, p. 97-101, 2000a.

SILVA, L. G. O. et al. Ecologia da comunidade parasitária do peixe-espada Trichiurus lepturus (Osteichthyes: Trichiuridae) do litoral do estado do Rio de Janeiro, Brasil. Revista Brasileira de Zoociencias, v. 3, n. 2, p. $115-133,2000 b$.
SZIDAT, L. Versuch einer Zoogeographie des Sud-Atlantik mit hilfe von LeitparaSiten der Meeresfische. Parasitologische Schriftenreihe, v. 2, n. 13, p. 1-98, 1961.

SZIDAT, L. Parasites of the palometa Parona signata (Jenyns, 1842) Berg, 1895 and their application on the zoogeographical problems of the South Atlantic. Neotropica, v. 15, n. 48, p. 125-131, 1969.

SZPILMAM, M. Peixes marinhos do Brasil: guia prático de identificação. Rio de Janeiro: Mauad Ltda., 2000. 288 p.

TAKEMOTO, R. M.; AMATO, J. F. R.; LUQUE, J. L. Trematódeos digenéticos parasitos de Oligoplites (Osteichthyes: Carangidae) do litoral do estado do Rio de Janeiro. Revista UNIMAR, v. 17, n. 2, p. $253-267,1995$.

TAKEMOTO, R. M.; AMATO, J. F. R.; LUQUE, J. L. Comparative analysis of the metazoan parasite communities of leatherjackets, Oligoplites palometa, O. saurus, and O. saliens (Osteichthyes: Carangidae) from Sepetiba Bay, Rio de Janeiro, Brazil. Revista Brasileira de Biologia, v. 56, n. 4, p. 639-650, 1996.

TANTALÉAN, M. V. Monogeneos de la familia Microcotylidae Taschenberg, 1879, parasitos de peces del mar peruano, con descripcion de una especie nueva. Biota, v. 10, n. 79, p. 120-127, 1974.

TAVARES, L. E. R.; BICUDO, A. J. A.; LUQUE, J. L. Metazoan parasites of needlefish Tylosurus acus (Lacepede, 1803) (Osteichthyes: Belonidae) from the coastal zone of the State of Rio de Janeiro, Brazil. Revista Brasileira de Parasitologia Veterinária, v. 13, n. 1, p. 36-40, 2004.

TAVARES, L. E. R.; LUQUE, J. L.; BICUDO, A. J. A. Community ecology of metazoan parasites of the anchovy Anchoa tricolor (Osteichthyes: Engraulidae) from the coastal zone of the State of Rio de Janeiro, Brazil. Brazilian Journal of Biology, v. 65, n. 3, p. 533-540, 2005.

TIMI, J. T. Parasites of from the coastal zone of the State of Rio de Janeiro, Brazil in the south-west Atlantic: latitudinal patterns and their use for discrimination of host populations. Journal of Fish Biology, v. 63 , n. 1 , p. $90-107,2003$.

TIMI, J. T.; MARTORELLI, S. R.; SARDELLA, N. H. Digenetic trematodes parasitic on Eugralis anchoita (Pisces: Engraulidae) from Argentina and Uruguay. Folia Parasitologica, v. 46, n. 2, p. 132-138, 1999.

TRAVASSOS, L.; FREITAS, J. F. T.; BÜHRNHEIM, P. F. Relatório da excursão do Instituto Oswaldo Cruz ao estado do Espírito Santo em novembro de 1964. Boletim do Museu de Biologia Professor Mello Leitáo, Zoologia, n. 31, p. 1-5, 1967.

VAZ, Z.; PEREIRA, C. Nouvel hemiuride parasite de Sardinella aurita Cuv. et al., Parahemiurus n. g. Compte Rendu des Séances de la Société de Biologie, v. 103, p. 1315-1317, 1930.

VICENTE, J. J.; SANTOS, E. Alguns helmintos de peixes do litoral norte fluminense. - I. Memórias do Instituto Oswaldo Cruz, v. 71, n. 1-2, p. 95-113, 1973.

WALLET, M.; KOHN, A. Trematodes parasites de poissons marins du littoral de Rio de Janeiro, Brasil. Memórias do Instituto Oswaldo Cruz, v. 82, n. 1, p. 21-27, 1987.

YAMAGUTI, S. Systema Helminthum, IV. Monogenea and Aspidocotylea. New York: Interscience Publication Inc., 1963. 699 p.

YAMAGUTI, S. Synopsis of digenetic trematodes of vertebrates. Tokyo: Keigaku, 1971a. 1074 p. 